\title{
HUBUNGAN AKTIVITAS FISIK TERHADAP KEKUATAN GENGGAMAN DAN KECEPATAN BERJALAN PADA LANSIA DI KELURAHAN PANJER
}

\author{
Vida Nanda Chattalia ${ }^{1}$, Indira Vidiari Juhanna ${ }^{2}$, Made Hendra Satria Nugraha ${ }^{3}$, Nila \\ Wahyuni $^{4}$ \\ ${ }^{1}$ Program Studi Sarjana Fisioterapi Dan Profesi Fisioterapi, Universitas Udayana \\ ${ }^{2,4}$ Departemen Faal, Fakultas Kedokteran, Universitas Udayana \\ ${ }^{3}$ Departemen Fisioterapi, Fakultas Kedokteran, Universitas Udayana
}

\section{E-Mail : vidanandachattalia@gmail.com}

\begin{abstract}
ABSTRAK
Pendahuluan: Penuaan menyebabkan perubahan struktur dalam tubuh manusia. Salah satunya adalah perubahan struktur otot sehingga menyebabkan penurunan kekuatan otot. Menurunnya kekuatan otot anggota gerak atas maupun bawah dapat mempengaruhi kemampuan fungsional seseorang karena terjadi penurunan kekuatan genggaman dan kecepatan berjalan. Memasuki masa lansia menyebabkan seseorang sulit untuk beradaptasi dengan lingkungan dan terlalu menutup diri dengan dunia luar. Padahal aktivitas fisik penting untuk dilakukan karena aktivitas fisik mampu meningkatkan kekuatan otot. Tujuan Penelitian: Mencari hubungan variabel aktivitas fisik terhadap kekuatan genggaman dan kecepatan berjalan pada lansia di Kelurahan Panjer. Metode: Penelitian menggunakan studi observasi analitik secara cross sectional, dilakukan di Panjer dari Maret 2019 - Mei 2019. Penelitian ini menggunakan subjek sebanyak 100 orang. Pengumpulan data dilakukan dengan mengukur aktivitas fisik menggunakan kuesioner Baecke Index, kekuatan genggaman menggunakan Hand-Grip Dynamometer dan pengukuran kecepatan berjalan dengan mengukur waktu berjalan pada lintasan sepanjang 4 meter. Hasil: Didapatkan $\mathrm{p}$ sebesar $(\mathrm{p}=0,000)$ untuk kekuatan genggaman dan $(\mathrm{p}=0,001)$ untuk kecepatan berjalan dari hasil uji chi-square. Uji hipotesis selanjutnya adalah korelasi kanonikal untuk menganalisis hubungan untuk semua variabel. Pada perhitungan analisis data, diperoleh hasil canonical loading sebesar 0,98531 untuk kekuatan genggaman, -0,69323 untuk kecepatan berjalan dan 1,00000 untuk aktivitas fisik sehingga semua hasil lebih tinggi dari nilai minimum 0,5. Kesimpulan: Berdasarkan hasil penelitian dan uji statistik tersebut maka dapat disimpulkan, (1) ada hubungan antara aktivitas fisik dengan kekuatan genggaman, (2) ada hubungan antara aktivitas fisik dengan kecepatan berjalan, dan (3) ada hubungan terhadap semua variabel.
\end{abstract}

Kata kunci : lansia, kekuatan genggaman, kecepatan berjalan, aktivitas fisik.

\section{THE CORRELATION BETWEEN PHYSICAL ACTIVITIES WITH HANDGRIP STRENGTH AND GAIT SPEED AMONG ELDERLY AT PANJER VILLAGE}

\section{ABSTRACT}

Introduction: Aging process causes structural changes of human body. One of them is a change in muscle structure, causing a decrease in muscle strength. Decreased muscle strength of all limbs can affect person's functional abilities such as decreased handgrip strength and gait speed. Entering an old age period causes elderly people to be less able to motivate themselves which will result in them being indolent to do physical activity and social interaction. In fact, physical activity is good to do because physical activity can increase muscle strength. Research purpose: To find out the correlation between physical activity to handgrip strength and gait speed elderly at Panjer Village. Method: This study using observational analytical study with a cross sectional study 
approach at Panjer in March 2019 to May 2019. It uses a subject of 100 people. Data collection was done by measuring physical activity using the Baecke Index questionnaire, using a Hand-Grip Dynamometer for measuring handgrip strength, and using gait time on a 4-meter long track for measuring gait speed. Results: Chi-square test obtained $p$ value of $(p=0,000)$ for handgrip strength and $(\mathrm{p}=0.001)$ for gait speed. The next hypothesis test is the canonical correlation to analyze the correlation for all variables. In the calculation of data analysis, canonical loading results obtained by 0.98531 for handgrip strength, -0.69323 for gait speed and 1.00000 for physical activity so that all results are higher than the minimum value of 0.5. Conclusion: Based on the results of the study and statistical tests, it can be concluded that, (1) there is a correlation between physical activity and handgrip strength, (2) there is a correlation between physical activity and gait speed, and (3) there is a correlation with all variables.

Keywords : elderly, handgrip strength, gait speed, physical activity.

\section{PENDAHULUAN}

Lanjut usia atau selanjutnya akan disebut dengan lansia adalah sebutan untuk orang yang sudah memiliki usia 60 tahun atau lebih dan secara fisiologis mengalami proses penurunan fungsi tubuh. ${ }^{1}$ Kelompok lansia tersebut akan mengalami proses penuaan atau aging process yang berdampak pada perubahan struktur tubuh. ${ }^{2}$ Dalam hal ini adalah kaitannya dengan perubahan sistem muskuloskeletal yaitu menurunnya kekuatan otot. $^{3}$ Penurunan kekuatan otot mulai berlangsung dari usia 40 tahun dan setelah usia 75 tahun keatas proses penurunan akan semakin cepat terjadi. ${ }^{4}$

Penurunan kekuatan otot pada lansia dapat mempengaruhi seluruh otot dalam tubuhnya baik itu otot tangan dan juga otot pada kaki. Penurunan kekuatan otot pada tangan dapat mempengaruhi kekuatan genggaman tangan pada lansia. Kekuatan genggaman memerlukan kombinasi aksi dari sejumlah otot pada tangan. Aksi ini sangat penting untuk aktivitas sehari-hari seperti melempar, mengangkat, makan, menangkap dan aktivitas lain yang menggunakan tangan untuk melakukannya. ${ }^{5}$ Kekuatan genggaman dapat menjadi ukuran pengganti dari keseluruhan kekuatan otot tubuh manusia, merupakan prediktor dari semua penyebab kematian pada populasi lansia dan dapat berfungsi sebagai alat yang mudah untuk prognostikasi risiko kematian di antara lansia. $^{6}$

Penurunan kekuatan otot pada kaki dapat mempengaruhi kecepatan berjalan pada lansia yang dalam hal ini dapat mengurangi kecepatan berjalan lansia. ${ }^{7}$ Otot-otot anggota gerak bawah terdiri dari otot-otot besar yang penting untuk melakukan gerakan ambulasi, sehingga penurunan kekuatan otot dapat mempengaruhi aktivitas berjalan. ${ }^{8}$ Gangguan mobilitas pada lansia merupakan salah satu dampak dari penurunan kekuatan otot, padahal kecepatan berjalan penting diperhatikan terkait aktivitas sehari-hari seperti berpindah dari satu lokasi kelokasi yang lain dan berjalan ke kamar mandi. ${ }^{9}$ Kecepatan berjalan sangat diperlukan terutama pada lansia dengan inkontinensia urin. Setiap kali terjadi inkontinensia urin pada lansia dan kecepatan berjalan juga menurun, akan mempengaruhi kelangsungan hidup sehari-hari pasien berhubungan dengan Activity Daily Living, kualitas hidup, peningkatan risiko jatuh dan fraktur. ${ }^{10}$

Memasuki masa lansia, menyebabkan seorang lansia dapat memiliki penurunan rasa percaya diri, depresi, sampai merasa terisolasi secara sosial. ${ }^{11}$ Kondisi tersebut menyebabkan lansia kurang mampu memotivasi diri sendiri yang akan mengakibatkan lansia malas untuk melakukan interaksi sosial sehingga banyak ditemui lansia yang hanya berdiam diri dirumah. ${ }^{12}$ Padahal aktivitas fisik penting untuk dilakukan karena dapat memberikan efek yang baik pada komponen muskuloskeletal. Aktivitas fisik yang dilakukan secara terus-menerus dapat memberikan peningkatan pada kekuatan otot. ${ }^{13}$ Aktivitas fisik yang dilakukan secara 
terus-menerus dan pola hidup sehat juga dapat mengurangi efek dari penuaan, sehingga usia hidup seseorang dapat meningkat. ${ }^{14}$

Berdasarkan pemaparan tersebut, disimpulkan bahwa melakukan aktivitas fisik secara teratur dapat mempengaruhi kekuatan genggaman dan kecepatan berjalan.

\section{METODE PENELITIAN}

Penelitian merupakan penelitian analytic dengan metode studi cross sectional di Kelurahan Panjer pada bulan Maret 2019 sampai Mei 2019. Sampel dipilih dengan teknik cluster sampling dan setelah disesuaikan dengan kriteria inklusi eksklusi didapatkan sampel 100 orang lansia.

Kriteria inklusi: bersedia sebagai subjek secara sukarela dengan menandatangani formulir persetujuan, berusia 60-74 tahun, status keseimbangan baik dilihat dari hasil TUGT $\leq 14$ detik, IMT normal berdasarkan kriteria Asia Pasifik. Sedangkan kriteria eksklusi: mengalami deformitas atau kelainan yang menyebaban ketidakmampuan dalam menggenggam dan berjalan, diketahui melalui wawancara terkait riwayat penyakit dan inspeksi (pemeriksaan dengan metode observasi) dan sedang mengkonsumsi obat yang dapat mempengaruhi kekuatan otot, diketahui melalui wawancara (obat golongan relaksan otot)

Subjek penelitian kemudian diwawancara dan dilakukan pengukuran aktivitas fisik menggunakan kuesioner Baecke Index, kekuatan genggaman menggunakan Hand-Grip Dynamometer dan pengukuran kecepatan berjalan dengan mengukur waktu berjalan pada lintasan sepanjang 4 meter. Data dianalisis dengan uji Chi-Square sebagai analisis bivariat dan uji korelasi kanonikal sebagai analisis multivariat.

\section{HASIL PENELITIAN}

\section{Karakteristik Subjek Penelitian}

Tabel 1. Karakteristik Sampel

\begin{tabular}{cccc}
\hline Variabel & $\begin{array}{c}\text { Frekue } \\
\text { nsi (n) }\end{array}$ & $\begin{array}{c}\text { Persent } \\
\text { ase }(\%)\end{array}$ & $\begin{array}{c}\text { Rerata } \\
\pm \mathrm{SB}\end{array}$ \\
\hline
\end{tabular}

Umur

$\begin{array}{lllc}\text { 60-64 tahun } & 29 & 29 & 67,70 \\ \text { 65-69 tahun } & 21 & 21 & \pm \\ \text { 70-74 tahun } & 50 & 50 & 5,177\end{array}$

Aktivitas

Fisik

$\begin{array}{lcc}\text { Rendah } & 4 & 4 \\ \text { Sedang } & 65 & 65 \\ \text { Tinggi } & 31 & 31\end{array}$

Kekuatan

Genggaman

$\begin{array}{lll}\text { Lemah } & 15 & 15 \\ \text { Normal } & 67 & 67 \\ \text { Kuat } & 18 & 18\end{array}$

Kecepatan

Berjalan

\begin{tabular}{lll} 
Buruk & 24 & 24 \\
Baik & 76 & 76 \\
\hline
\end{tabular}

Berdasarkan Tabel 1, rerata umur subjek pada penelitian ini adalah 67,70 \pm 5,177, antara usia 60 tahun dan 74 tahun. Sebanyak 31 orang subjek memiliki aktivitas fisik tinggi, 65 orang memiliki aktivitas sedang dan 4 orang memiliki aktivitas fisik rendah. Subjek dengan kekuatan genggaman kuat sebanyak 18 orang, kekuatan genggaman normal sebanyak 67 orang dan dengan kekuatan genggaman lemah sebanyak 15 orang. Subjek dengan kecepatan berjalan baik sebanyak 76 orang dan dengan kecepatan berjalan buruk sebanyak 24 orang.

\section{Hubungan Aktivitas Fisik dan Kekuatan Genggaman}

Tabel 2. Hubungan Aktivitas Fisik dan Kekuatan Genggaman

\begin{tabular}{cccccc}
\hline & \multicolumn{3}{c}{ Kekuatan } & Total & $\mathrm{p}$ \\
\cline { 2 - 5 } Aktivit & Le & Nor & Kua & & \\
as Fisik & $\begin{array}{c}\text { mah } \\
\text { mal }\end{array}$ & $\mathrm{t}$ & & \\
\cline { 2 - 5 } & $\mathrm{n}$ & $\mathrm{n}$ & $\mathrm{n}$ & $\mathrm{n}$ & \\
Rendah & 3 & 1 & 0 & 4 & \\
Sedang & 12 & 49 & 4 & 65 & \\
Tinggi & 0 & 17 & 14 & 31 & 0,000 \\
Jumlah & 15 & 67 & 18 & 100 & \\
\hline
\end{tabular}

Berdasarkan Tabel 2, menunjukkan hasil $(\mathrm{p}<0,05)$ yang berarti ada hubungan 
signifikan antara aktivitas fisik dan kekuatan genggaman.

\section{Hubungan Aktivitas Fisik dan Kecepatan Berjalan}

Tabel 3. Hubungan Aktivitas Fisik dan Kecepatan Berjalan

\begin{tabular}{ccccc}
\hline & \multicolumn{2}{c}{$\begin{array}{c}\text { Kecepatan } \\
\text { Berjalan }\end{array}$} & Total & $\mathrm{p}$ \\
\cline { 2 - 4 } $\begin{array}{c}\text { Aktivita } \\
\text { s Fisik }\end{array}$ & Buruk & Baik & & \\
\cline { 2 - 4 } & $\mathrm{n}$ & $\mathrm{n}$ & $\mathrm{n}$ & \\
Rendah & 3 & 1 & 4 & \\
Sedang & 20 & 45 & 65 & 0,001 \\
Tinggi & 1 & 30 & 31 & \\
Jumlah & 24 & 76 & 100 & \\
\hline
\end{tabular}

Berdasarkan Tabel 3, menunjukkan hasil $(\mathrm{p}<0,05)$ yang berarti ada hubungan signifikan antara aktivitas fisik dan kecepatan berjalan.

\section{Hubungan Aktivitas Fisik, Kekuatan Genggaman dan Kecepatan Berjalan}

Tabel 4. Output Canonical

\begin{tabular}{lccc}
\hline \multicolumn{1}{c}{ Variabel } & & $\begin{array}{c}\text { Canonical } \\
\text { Weight }\end{array}$ & $\begin{array}{c}\text { Canonical } \\
\text { Loading }\end{array}$ \\
\hline $\begin{array}{l}\text { Kekuatan } \\
\text { Genggaman }\end{array}$ & Y1 & 0,86991 & 0,98531 \\
$\begin{array}{l}\text { Kecepatan } \\
\text { Berjalan }\end{array}$ & Y2 & $-0,20609$ & $-0,69323$ \\
$\begin{array}{l}\text { Aktivitas } \\
\text { Fisik }\end{array}$ & $\mathrm{X} 1$ & 1,00000 & 1,00000 \\
\hline
\end{tabular}

Berdasarkan Tabel 4, hasil menunjukkan hubungan signifikan antara dependen variabel yaitu kekuatan genggaman dan kecepatan berjalan dan independen variabel yaitu aktivitas fisik (canonical loading > 0,5) atau bisa disebut kekuatan genggaman berkorelasi positif dan kecepatan berjalan berkorelasi negatif terhadap aktivitas fisik. Aktivitas fisik semakin banyak maka semakin tinggi kekuatan genggaman dan semakin baik kecepatan berjalannya.

\section{PEMBAHASAN}

Dalam penelitian ini dapat dilihat bahwa lansia di Kelurahan Panjer lebih banyak yang memiliki aktivitas fisik sedang. Lebih tua usia lansia, maka aktivitas fisiknya cenderung lebih sedikit. Hal tersebut disebabkan karena semakin tinggi usia tingkat ketahanan tubuh semakin menurun dan variasi dan jumlah kegiatan yang dapat dilakukan juga semakin berkurang. ${ }^{15}$ Banyaknya aktivitas fisik lansia dipengaruhi oleh pekerjaan yang dilakukan. Lansia yang masih memiliki pekerjaan akan beraktivitas lebih banyak dibandingkan dengan lansia yang sudah tidak bekerja. ${ }^{16}$ Lansia di kota khususnya di lingkungan Kelurahan Panjer aktivitas fisik yang dilakukan akan dikaitkan dengan lingkungan tempat tinggal, lansia yang tinggal di perkotaan banyak didukung oleh sektor ekonomi, fasilitas dan teknologi yang memadai sehingga aktivitas fisiknya menjadi lebih ringan. ${ }^{17}$

Pada penelitian ini nilai $p$ sebesar 0,000 menunjukkan bahwa ada hubungan antara aktivitas fisik terhadap kekuatan genggaman. Serupa dengan penelitian Lenardt, et al tahun 2016, didapatkan hasil bahwa lansia yang mengalami penurunan handgrip strength adalah lansia dengan tingkat aktivitas fisik rendah. ${ }^{18}$ Selaras dengan penelitian Kuh, et al tahun 2005, di mana penulis menyatakan bahwa variabel aktivitas fisik pada orang tua secara signifikan terkait dengan kekuatan pegangan yang rendah. ${ }^{19}$ Penelitian ini didukung oleh penelitian Sekarsari, et al tahun 2018, mengatakan terdapat korelasi yang signifikan dan positif ditemukan antara handgrip strength dengan PAL atau physical activity level. ${ }^{20}$

Pada penelitian ini nilai $p$ sebesar 0,001 menunjukkan ada hubungan antara aktivitas fisik terhadap kecepatan berjalan. Hasil serupa dengan penelitian oleh Haider, et al tahun 2016, yang menyebutkan antara daily physical activity dan gait speed terdapat hubungan. ${ }^{21}$ Selaras dengan penelitian Spartano, et al tahun 2018 yang menjelaskan antara aktivitas ringan dengan kecepatan berjalan terdapat hubungan. ${ }^{22}$ Penelitian oleh Izawa, et al tahun 2015, menjelaskan bahwa hubungan maximum gait speed dan PA atau 
physical activity pasien di rumah sakit menghasilkan hubungan yang positif. ${ }^{23}$ Sejalan dengan penelitan oleh Busch, et al tahun 2015 yang menjelaskan bahwa kecepatan berjalan yang lebih rendah dikaitkan dengan faktor yang dapat dimodifikasi seperti kurang aktivitas fisik. ${ }^{24}$

Aktivitas fisik penting untuk dilakukan karena dapat memberikan efek yang baik pada sistem muskuloskeletal. Aktivitas fisik yang dilakukan secara terusmenerus dapat memberikan peningkatan pada kekuatan otot. $^{13}$ Kontraksi otot saat melakukan aktivitas menyebabkan sintesis protein kontraktil otot berlangsung lebih cepat, sehingga terjadi penambahan secara progresif filamen aktin miosin dalam miofibril. Pada setiap serat otot, akan terjadi pemecahan untuk membentuk miofibril baru, pembentukan yang makin banyak menyebabkan terjadi hipertrofi serat otot. Hipertrofi menyebabkan peningkatan fosfagen, seperti fosfokreatin dan ATP. Hal inilah yang menyebabkan kapasitas sistem metabolisme aerob dan anaerob akan meningkat sehingga berpengaruh pada meningkatkan kekuatan otot. ${ }^{25}$

Berdasarkan paparan diatas, maka faktor-faktor tersebut akan ditentukan korelasinya dengan korelasi kanonik. Bobot kanonik atau canonical weight, adalah koefisien kanonik yang telah baku, sehingga dapat dijadikan interpretasi besarnya keeratan variabel asal atas variabel kanoniknya. Nilai bobot kanonik menunjukkan seberapa besar pengaruh peubah asal terhadap peubah kanoniknya. Nilai bobot kanonik jarang dijadikan interpretasi fungsi kanonik karena memiliki beberapa kelemahan. Kelemahan tersebut adalah bobot kanonik semata-mata menggambarkan besarnya kontribusi peubah asal atas peubah kanoniknya, yang dinilai tidak relevan untuk menggambarkan hubungan antar peubah. Nilai ini juga dikatakan tidak relevan karena rentan adanya multikolinieritas dan satu sampel ke sampel lain sangat tidak stabil. Beban kanonik atau canonical loading disebut juga dengan korelasi struktur, berfungsi menilai korelasi linier sederhana antara variabel independen atau dependen pada peubah kanoniknya. Nilai beban kanonik akan lebih baik dijadikan interpretasi hubungan dibandingkan dengan bobot kanonik oleh karena kelemahan yang sudah disebutkan sebelumnya. Bobot dan beban kanonikal memiliki nilai rujukan > $0,5 .^{26}$

Pada Tabel 4, dapat dilihat peubah yang memberikan peran lebih pada peubah kanoniknya memiliki nilai koefisien lebih besar. Peubah dengan tanda sama mempunyai hubungan langsung searah dan peubah yang berlawanan tanda, mempunyai hubungan berkebalikan dengan peubah kanonik lainnya. ${ }^{26}$ Dari hasil angka koefisien diatas didapatkan hasil bahwa efek tingkat aktivitas fisik lansia lebih mempengaruhi nilai kekuatan genggaman seseorang dan adanya hubungan signifikan antara variabel dependen yaitu kekuatan genggaman dan kecepatan berjalan dan variabel independen yaitu aktivitas fisik atau bisa disebut kekuatan genggaman berkorelasi positif dan kecepatan berjalan berkorelasi negatif terhadap aktivitas fisik. Seiring dengan tingginya tingkat aktivitas fisik lansia kekuatan genggaman akan semakin tinggi dan semakin baik kecepatan berjalannya.

Hasil penelitian ini selaras dengan penelitian Willey, et al tahun 2017, yang menjelaskan bahwa ketidakaktifan secara fisik dikaitkan dengan kecepatan berjalan yang lebih lambat secara independen, kekuatan genggaman dan cedera otak iskemik subklinis. Sehingga memodifikasi perilaku tidak aktif menjadi sasaran intervensi untuk mengurangi penurunan mobilitas. ${ }^{27}$ Dalam studi lain oleh Sekarsari, et al tahun 2018, menjelaskan bahwa korelasi positif yang signifikan ditemukan antara kekuatan genggaman dengan kecepatan berjalan dan physical activity level. ${ }^{20}$

\section{KELEMAHAN PENELITIAN}

Kelemahan dalam penelitian ini adalah hasil penelitian hanya menggambarkan ada atau tidaknya hubungan antara aktivitas fisik terhadap kekuatan genggaman dan kecepatan berjalan sehingga kuat hubungan dan arah hubungan tidak diketahui. Kelemahan lainnya adalah penelitian ini dilakukan dengan mencari lansia ke rumah 
mereka masing-masing sehingga bentuk dan jenis permukaan lintasan kecepatan berjalan akan berbeda-beda setiap lansia.

\section{SIMPULAN}

Berdasarkan hasil yang diperlihatkan diatas, maka kesimpulannya adalah:

1. Adanya hubungan yang signifikan antara aktivitas fisik dan kekuatan genggaman pada lansia di Kelurahan Panjer

2. Adanya hubungan yang signifikan antara aktivitas fisik dan kecepatan berjalan pada lansia di Kelurahan Panjer.

3. Adanya hubungan antara aktivitas fisik terhadap kekuatan genggaman dan kecepatan berjalan pada lansia di Kelurahan Panjer.

\section{DAFTAR PUSTAKA}

1. RI, Kementerian Kesehatan. 2017. Analisis Lansia di Indonesia. Pusat data dan Informasi Kementerian Kesehatan RI. Jakarta Selatan.

2. Fatmah. 2010. Buku Gizi Usia Lanjut. Erlangga.

3. Nejc, S., Loefler, S., Cvecka, J., Sedliak, M., Kern, H. 2013. Strength training in elderly people improves static balance: a randomized controlled trial. European Journal Translational Myology. Vol 23 No 3.

4. Andersson, DC., Betzenhauser, MJ., Reiken, S., Meli, AC., Umanskaya, A., Wenjun, X., Shiomi, T., Zalk, R., Lacampagne, A., Marks, AR. 2011. Ryanodine Receptor Oxidation Causes Intracellular Calcium Leak and Muscle Weakness in Aging. Cell Metabolism Article. Vol 14 No 2.

5. Rolland, Y., Vellas, B. 2010. Sarcopenia, Brocklehurst's Textbook of Geriatric. Philadelphia: Elsevier. 587-593.

6. Ling, CH., Taekema, D., de Craen, AJ., Gussekloo, J., Westendorp, RG., Maier, AB. 2010. Handgrip strength and mortality in the oldest old population: the Leiden 85-plus study. CMAJ. Vol 182 No 5.
7. Quach, L., Galica, AM., Jones, RN., Gray, EP., Manor, B., Hannan, MT., Lipsitz, LA. 2011. The Non-linear Relationship between Gait Speed and Falls: The Mobilize Boston Study. J Am Geriatr Soc. Vol 59 No 6.

8. Utomo, B. 2010. Hubungan antara Kekuatan Otot dan Daya Tahan Otot Anggota Gerak Bawah dengan Kemampuan Fungsional Lanjut Usia. Program Pascasarjana Universitas Sebelas Maret. Surakarta.

9. Manty, M., Leon, CF., Rantanen, T., Era, P., Pedersen, AN., Ekmann, A., Schroll, M., Avlund, K. 2011. Mobility-Related Fatigue, Walking Speed, and Muscle Strength in Older People. Journal of Gerontology. 67(5):523-9.

10. Atmis, V., Guler, B. 2019. Association Between Walking Speed and Urinary Incontinence in the Older Women. Which Patients Should be Referred to Geriatricians?. Gynecology Obstetrics \& Reproductive Medicine.

11. Nugraha, MHS., Nila, W., Muliarta, IM. 2016. Pelatihan 12 Balance Exercise Lebih Meningkatkan Keseimbangan Dinamis Daripada Balance Strategy Exercise pada Lansia di Banjar Bumi Shanti, Desa Dauh Puri Kelod, Kecamatan Denpasar Barat. Majalah Ilmiah Fisioterapi Indonesia. Vol. 4 No. 1.

12. Sartiwi, Widodo, D., Widianti, E. 2017. Hubungan Kondisi Fisik Dengan Kecerdasan Emosional Pada Lanjut Usia Di Kelurahan Tlogomas Kota Malang. Malang: Nursing News.

13. Ryoto, V. 2012. Hubungan Antara Kekuatan Otot Genggam dengan Umur, Tingkat Kemandirian dan Aktivitas Fisik pada Lansia Wanita Klub Geriatri Terpilih. Jakarta Utara: Universitas Indonesia.

14. Juhanna, IV., Adiatmika, IPG., Adiputra, LMI., Tirtayasa, K., Muliarta, M., Griadhi, A., 2017. High Intensity Interval Training (HIIT) Lebih Meningkatkan Ambang Anaerobik Daripada Steady State Trainingpada Siswa Anggota Kelompok Ekstrakurikuler Atletik Lari Jarak Pendek. Sport and Fitness Journal. Vol 5 No 3.

15. Ismayanti., Nurika., Solikhah. 2011. Hubungan Antara Pola Konsumsi dan 
Aktivitas Fisik dengan Status Gizi pada Lansia di Panti Sosial Tresna Werdha Unit Abiyoso Yogyakarta. Jurnal Kesehatan Masyarakat. Vol 6 No 3.

16. Kartika Sari, AD., Wirjatmadi, B. 2017. Hubungan Aktivitas Fisik Dengan Kejadian Konstipasi Pada Lansia Di Kota Madiun. Universitas Airlangga. Surabaya.

17. Putra, KP., Kurniasari, MD., Purnamasiwi, A. 2018. Analisa Hubungan Aktivitas Fisik Terhadap Kondisi Fisik Lansia Di Desa Dan Kota. Universitas Kristen Satya Wacana. Salatiga.

18. Lenardt, MH., Binotto, MA., Carneiro, NH., Cechinel, C., Betiolli, SE., Lourenco, TM. 2016. Handgrip Strength and Physical Activity in Frail Elderly. Journal of School of Nursing. Vol 50 No 1.

19. Kuh, D., Bassey, EJ., Butterworth, S., Hardy, R., Wadsworth, ME. 2005. Grip Strength, Postural Control and Functional Leg Power in a Representative Cohort of British Men and Women: Associations With Physical Activity, Health Status, and Socioeconomic Conditions. Journal of Gerontology. Vol 60 No 2.

20. Sekarsari, S., Vitriana., Defi, IR. 2018. Correlation between Handgrip Strength, Mobilization Function, Physical Activity Level and Muscle Mass in CommunityDwelling Elderly in Bandung, West Java Province, Indonesia. International Journal of Integrated Health Sciences. Vol 6 No 1.

21. Haider, S., Luger, E., Kapan, A., Titze, S., Lackinger, C., Schindler, KE., Dorner, TE. 2016. Associations between daily physical activity, handgrip strength, muscle mass, physical performance and quality of life in prefrail and frail community-dwelling older adults. Qual Life Res. Vol 25 No 12.

22. Spartano, N.L., Lyass, A., Larson, MG., Vasan, RS., Murabito, JM. 2018. Relations of Physical Activity to Gait Speed in Older Adults From the Framingham Offspring Study: Effect Modification by Age. AHA Journals.

23. Izawa, KP., Watanabe, S., Hirano, Y., Matsushima, S., Suzuki, T., Oka, K., Kida, K., Suzuki, K., Osada, N., Omiya, K., Brubaker, PH., Shimizu, H., Akashi, YJ. 2015. Gender - related Differences in
Maximum Gait Speed and Daily Physical Activity in Elderly Hospitalized Cardiac Inpatients. md-journal. Vol 94 No 11.

24. Busch, TA., Duarte, YA., Nunes, DP., Lebrao, ML., Naslavsky, M.S., Rodrigues, AS., Jr, EA. 2015. Factors associated with lower gait speed among the elderly living in a developing country : a cross-sectional population-based study. BMC Geriatrics. $15: 35$

25. Widyantoro, AP., Rosdiana, I., Fasitasari, M. 2012. Hubungan antara Senam Lansia dan Range of Motion (ROM) Lutut pada Lansia. Semarang: Universitas Islam Sultan Agung.

26. Hair, J., Anderson, R., Tatham, R., Black, W. 2010. Multivariate Data Analysis With Reading, Seventh Edition. Prentice Hall International Edition. New Jersey.

27. Willey, JZ., Yeseon, PM., Erin, RK., Ying, CK., Clinton, BW., Ralph, LS., Mitchell, SE. 2017. Physical inactivity predicts slow gait speed in an elderly multi ethnic cohort study : the Northern Manhattan Study (NOMAS). HHS Public Access. 49(1-2): 24-30. 